Head and Neck Cancer 


\section{Cancer Treatment and Research}

Lippman M.E., Dickson R. (eds): Breast Cancer: Cellular and Molecular Biology. 1988. ISBN 0-89838-368-4.

Kamps W.A., Humphrey G.B., Poppema S. (eds): Hodgkin's Disease in Children: Controversies and Current Practice. 1988. ISBN 0-89838-372-2.

Muggia F.M. (ed): Cancer Chemotherapy: Concepts, Clinical Investigations and Therapeutic Advances. 1988. ISBN 0-89838-381-1.

Nathanson L. (ed): Malignant Melanoma: Biology, Diagnosis, and Therapy. 1988. ISBN 0-89838-384-6.

Pinedo H.M., Verweij J. (eds): Treatment of Soft Tissue Sarcomas. 1989. ISBN 0-89838-391-9.

Hansen H.H. (ed): Basic and Clinical Concepts of Lung Cancer. 1989. ISBN 0-7923-0153-6.

Lepor H., Ratliff T.L. (eds): Urologic Oncology. 1989. ISBN 0-7923-0161-7.

Benz C., Liu E. (eds): Oncogenes. 1989. ISBN 0-7923-0237-0.

Ozols R.F. (ed): Drug Resistance in Cancer Therapy. 1989. ISBN 0-7923-0244-3.

Surwit E.A., Alberts D.S. (eds): Endometrial Cancer. 1989. ISBN 0-7923-0286-9.

Champlin R. (ed): Bone Marrow Transplantation. 1990. ISBN 0-7923-0612-0.

Goldenberg D. (ed): Cancer Imaging with Radiolabeled Antibodies. 1990. ISBN 0-7923-0631-7.

Jacobs C. (ed): Carcinomas of the Head and Neck. 1990. ISBN 0-7923-0668-6.

Lippman M.E., Dickson R. (eds): Regulatory Mechanisms in Breast Cancer: Advances in Cellular and Molecular Biology of Breast Cancer. 1990. ISBN 0-7923-0868-9.

Nathanson L. (ed): Malignant Melanoma: Genetics, Growth Factors, Metastases, and Antigens. 1991. ISBN 0-7923-0895-6.

Sugarbaker P.H. (ed): Management of Gastric Cancer. 1991. ISBN 0-7923-1102-7.

Pinedo H.M., Verweij J., Suit H.D. (eds): Soft Tissue Sarcomas: New Developments in the Multidisciplinary Approach to Treatment. 1991. ISBN 0-7923-1139-6.

Ozols R.F. (ed): Molecular and Clinical Advances in Anticancer Drug Resistance. 1991. ISBN 0-7923-1212-0.

Muggia F.M. (ed): New Drugs, Concepts and Results in Cancer Chemotherapy. 1991. ISBN 0-7923-1253-8.

Dickson R.B., Lippman M.E. (eds): Genes, Oncogenes and Hormones: Advances in Cellular and Molecular Biology of Breast Cancer. 1992. ISBN 0-7923-1748-3.

Humphrey G. Bennett, Koops H. Schraffordt, Molenaar W.M., Postma A. (eds): Osteosarcoma in Adolescents and Young Adults: New Developments and Controversies. 1993. ISBN 0-7923-1905-2.

Benz C.C., Liu E.F. (eds): Oncogenes and Tumor Suppressor Genes in Human Malignancies. 1993. ISBN 0-7923-1960-5.

Freireich E.J., Kantarjian H. (eds): Leukemia: Advances in Research and Treatment. 1993. ISBN 0-7923-1967-2.

Dana B.W. (ed): Malignant Lymphomas, Including Hodgkin's Disease: Diagnosis, Management and Special Problems. 1993. ISBN 0-7923-2171-5.

Nathanson L. (ed): Current Research and Clinical Management of Melanoma. 1993. ISBN 0-7923-2152-9.

Verweij J., Pinedo H.M., Suit H.D. (eds): Multidisciplinary Treatment of Soft Tissue Sarcomas. 1993. ISBN 0-7923-2183-9.

Rosen S.T., Kuzel T.M. (eds): Immunoconjugate Therapy of Hematologic Malignancies. 1993. ISBN 0-7923-2270-3.

Sugarbaker P.H. (ed): Hepatobiliary Cancer. 1994. ISBN 0-7923-2501-X.

Rothenberg M.L. (ed): Gynecologic Oncology: Controversies and New Developments. 1994. ISBN 0-7923-2634-2.

Dickson R.B., Lippman M.E. (eds): Mammary Tumorigenesis and Malignant Progression. 1994. ISBN 0-7923-2647-4.

Hansen H.H. (ed): Lung Cancer. Advances in Basic and Clinical Research. 1994. ISBN 0-7923-2835-3.

Goldstein L.J., Ozols R.F. (eds): Anticancer Drug Resistance. Advances in Molecular and Clinical Research. 1994. ISBN 0-7923-2836-1. 


\section{Head and Neck Cancer}

Basic and Clinical Aspects

edited by

Waun Ki Hong, M.D.

The University of Texas

M. D. Anderson Cancer Center

Houston, Texas

Randal S. Weber, M.D.

The University of Texas

M. D. Anderson Cancer Center

Houston, Texas 


\section{Library of Congress Cataloging-in-Publication Data}

Head and neck cancer: basic and clinical aspects/edited by Waun Ki Hong,

Randal S. Weber.

p. $\quad \mathrm{cm} .-$ (Cancer treatment and research; CTAR 74)

Includes bibliographical references and index.

ISBN 978-1-4613-5837-4 ISBN 978-1-4615-2023-8 (eBook)

DOI 10.1007/978-1-4615-2023-8

1. Head - Cancer. 2. Neck - Cancer. I. Hong, Waun

Ki. II. Weber, Randal S. III. Series: Cancer treatment and research; v. 74 .

[DNLM: 1. Head and Neck Neoplasms. W1 CA693 v. 74 1994/

WE 707 H43173 1994]

RC280.H4H3848 1994

$616.99^{\prime} 491-\mathrm{dc} 20$

DNLM/DLC

for Library of Congress

Copyright (C) 1995 by Springer Science+Business Media New York

Originally published by Kluwer Academic Publishers in 1995

Softcover reprint of the hardcover 1st edition 1995

All rights reserved. No part of this publication may be reproduced, stored in a retrieval system or transmitted in any form or by any means, mechanical, photo-copying, recording, or otherwise, without the prior written permission of the publisher, Springer-Science+Business Media, LLC

Printed on acid-free paper. 


\section{Contents}

Preface vii

Acknowledgments $\quad$ ix

Contributing Authors $\quad$ xi

1. Role of Human Papillomaviruses in Benign and Malignant Lesions 1 BETTIE M. STEINBERG

2. Molecular Phenotyping of Head and Neck Cancer DONG M. SHIN and MICHAEL A. TAINSKY

3. Squamous Differentiation and Retinoids REUBEN M. LOTAN

4. Risk Factors and Genetic Susceptibility MARGARET R. SPITZ

5. Biology and Reversal of Aerodigestive Tract Carcinogenesis

SCOTT M. LIPPMAN, GARY L. CLAYMAN, MARTIN H. HUBER, STEVEN E. BENNER and WAUN KI HONG

6. Mechanisms of Invasion by Head and Neck Cancers DOUGLAS D. BOYD and GARTH L. NICOLSON

7. Cellular and Molecular Mechanisms of Radioresistance RALPH R. WEICHSELBAUM, MICHAEL A. BECKETT, EVERETT E. VOKES, DAVID G. BRACHMAN, DANIEL HARAF, DENNIS HALLAHAN and DONALD KUFE

8. Early Detection and Screening for Head and Neck Cancer

JACK L. GLUCKMAN and ROBERT P. ZITSCH 
9. Photodynamic Therapy for Cancer of the Head and Neck

JACK L. GLUCKMAN and LOUIS G. PORTUGAL

10. Timing and Sequencing of Chemoradiotherapy

DANIEL J. HARAF, RALPH R. WEICHSELBAUM and

EVERETT E. VOKES

11. Organ Preservation in Advanced Head and Neck Cancer

CHARLES R. DIBB, SUSAN G. URBA and GREGORY T. WOLF

12. Elective Modified Neck Dissection for Treatment of the Clinically Negative (N0) Neck

DAVID L. CALLENDER and RANDAL S. WEBER

13. Distant Metastases from Head and Neck Squamous

Cancer: The Role of Adjuvant Chemotherapy

HARLAN A. PINTO and CHARLOTTE JACOBS

14. Experimental Therapeutic Approaches for Recurrent Head and Neck Cancer

ARLENE A. FORASTIERE and SUSAN G. URBA

15. Head and Neck Cancer: The Year 2000 HELMUTH GOEPFERT

Index 


\section{Preface}

Throughout the world, head and neck cancer is a major threat to public health and a significant challenge to both clinicians and basic scientists. Despite extensive efforts in primary prevention, screening, early detection, and therapy, long-term survival rates have not improved substantially in the last three decades. This book covers a wide range of exciting new findings in both clinical and basic sciences as they are relevant to head and neck cancer. These findings have recently enhanced our understanding of head and neck carcinogenesis at the genetic and molecular levels, offering the promise of improved preventive and therapeutic strategies. This book will also present information on the important clinical advances that have been made in chemoprevention, organ preservation, and the simultaneous use of chemotherapy and radiotherapy.

The first part provides an overview of the etiology and biology of head and neck cancer, including an examination of human papillomaviruses in both benign and malignant lesions. This section also discusses the carcinogenic process at the genetic and molecular levels, as well as aberrant squamous differentiation; increased understanding of these areas has great potential to translate into new strategies for cancer prevention. The second part describes recent advances in developing a risk model for head and neck cancer, as well as the application of genetic susceptibility data in chemoprevention. This section also includes overviews of the status of chemoprevention trials and of the process of invasion and metastasis in head and neck cancer.

The third part covers molecular studies of radioresistance, early detection of head and neck cancer, and the implications of photodynamic therapy, while the fourth section includes studies of the timing and sequencing of chemoradiotherapy. New strategies in this area have significantly increased the feasibility of laryngeal preservation in the treatment of advanced laryngeal cancer. The fifth and last part discusses the management of clinically negative neck disease, the role of adjuvant therapy in preventing distant metastasis, and new strategies for the treatment of recurrent tumors. Finally, we close with some intriguing predictions for the future of head and neck cancer therapy. 
Our goal is to provide a summary of the state of the art in head and neck cancer, so that practicing physicians can determine how these findings will influence the management of their patients. The participation of the many specialties represented by the authors emphasizes the importance of multidisciplinary care for the head and neck cancer patient.

WAUN KI HONG RANDAL S. WEBER 


\section{Acknowledgments}

The editors would like to express their deep appreciation to the authors for submitting their manuscripts in a timely manner. We would also like to thank Arianne O'Loughlin for her efforts in editing the manuscripts and making this project a success. 


\section{Contributing Authors}

BECKETT, MICHAEL A., Laboratory Manager, Department of Radiation and Cellular Oncology, University of Chicago Medical Center, 5841 South Maryland Avenue, MC0085, Chicago, IL 60637

BENNER, STEVEN E., M.D., Associate Professor of Medicine, Division of Medical Oncology, University of North Carolina, Chapel Hill, CB 7305, Chapel Hill, NC 27599

BOYD, DOUGLAS D., Ph.D., Assistant Professor of Tumor Biology, Department of Tumor Biology, The University of Texas M. D. Anderson Cancer Center, 1515 Holcombe Boulevard, Box 108, Houston, TX 77030 CALLENDER, DAVID L., M.D., Assistant Professor of Surgery, Department of Head and Neck Surgery, The University of Texas M. D. Anderson Cancer Center, 1515 Holcombe Boulevard, Box 69, Houston, TX 77030

CLAYMAN, GARY L., D.D.S., M.D., Assistant Professor of Surgery, Department of Head and Neck Surgery, The University of Texas M. D. Anderson Cancer Center, 1515 Holcombe Boulevard, Box 69, Houston, TX 77030

DIBB, CHARLES R., M.D., Medford Clinic, 555 Black Oak Drive, Medford, OR 97504

FORASTIERE, ARLENE A., M.D., Associate Professor of Medicine, The Johns Hopkins Oncology Center, Johns Hopkins University School of Medicine, 600 North Wolfe Street, Baltimore, MD 21287-8936

GLUCKMAN, JACK L., M.D., Professor and Chairman, Department of Otolaryngology - Head and Neck Surgery, University of Cincinnati Medical Center, Mail Location 0528, 231 Bethesda Avenue, Cincinnati, OH 45267-0528

GOEPFERT, HELMUT, M.D., Professor and Chairman, Department of Head and Neck Surgery; M.G. and Lillie A. Johnson Chair for Cancer Treatment and Research, Department of Head and Neck Surgery, The University of Texas M. D. Anderson Cancer Center, 1515 Holcombe Boulevard, Box 69, Houston, TX 77030

HALlAHAN, DENNIS, M.D., Assistant Professor, Department of Radiation and Cellular Oncology, University of Chicago Medical Center, 
5841 South Maryland Avenue, MC0085, Chicago, IL 60637

HARAF, DANIEL., M.D. Assistant Professor, Department of Radiation and Cellular Oncology, University of Chicago Medical Center, 5841 South Maryland Avenue, MC0085, Chicago, IL 60637

HONG, WAUN K., M.D., Professor and Chairman, Department of Thoracic/Head, and Neck Medical Oncology, Charles A. LeMaistre Chair in Thoracic Oncology, The University of Texas M. D. Anderson Cancer Center, 1515 Holcombe Boulevard, Box 80, Houston, TX 77030

HUBER, MARTIN H., M.D., Assistant Internist and Assistant Professor of Medicine, Department of Thoracic/Head and Neck Medical Oncology, The University of Texas M. D. Anderson Cancer Center, 1515 Holcombe Boulevard, Box 80, Houston, TX 77030

JACOBS, CHARLOTTE, M.D., Senior Associate Dean for Education and Student Affairs, Vice President and Dean's Office, M121 School of Medicine, Stanford University, Stanford, CA 94505

KUFE, DONALD, M.D., Chief, Division of Cancer Pharmacology, DanaFarber Cancer Institute, Division of Cancer Pharmacology, 44 Binney Street, Room D1730, Boston, MA 02115

LIPPMAN, SCOTT M., M.D., Associate Professor of Medicine, Chief of Section of Head and Neck Medical Oncology, Department of Thoracic/ Head and Neck Medical Oncology, The University of Texas M. D. Anderson Cancer Center, 1515 Holcombe Boulevard, Box 80, Houston, TX 77030

LOTAN, REUBEN M., Ph.D., Professor of Tumor Biology, Deputy Chairman, Department of Tumor Biology, Abell-Hanger Foundation Professor, The University of Texas M. D. Anderson Cancer Center, 1515 Holcombe Boulevard, Box 108, Houston, TX 77030

NICOLSON, GARTH L., Ph.D., Professor of Tumor Biology, Chairman, Department of Tumor Biology, David Bruton, Jr. Chair in Cancer Research, The University of Texas M. D. Anderson Cancer Center, 1515 Holcombe Boulevard, Box 108, Houston, TX 77030

PINTO, HARLAN A., M.D., Assistant Professor of Medicine, Division of Medical Oncology, Room M211, Stanford University Medical Center, Stanford, CA 94505

PORTUGAL, LOUIS G., M.D., Assistant Professor of Medicine, University of Illinois Eye and Ear Infirmary, Department of Otolaryngology Head and Neck Surgery, 1855 West Taylor Street, Chicago, IL 60612

SHIN, DONG M., M.D., Assistant Internist and Assistant Professor of Medicine, Department of Thoracic/Head and Neck Medical Oncology, The University of Texas M. D. Anderson Cancer Center, 1515 Holcombe Boulevard, Box 80, Houston, TX 77030

SPITZ, MARGARET R., M.D., M.P.H., Acting Chair, Department of Epidemiology, The University of Texas M. D. Anderson Cancer Center, 1515 Holcombe Boulevard, Box 189, Houston, TX 77030 STEINBERG, BETTIE M., Ph.D., Chief, Division of Otolaryngologic 
Research, LIJMC, Associate Professor, Otolaryngology, Albert Einstein College of Medicine, Long Island Jewish Medical Center, Department of Otolaryngology and Communicative Disorders, New Hyde Park, NY 11042

TAINSKY, MICHAEL A., Ph.D., Associate Biologist, Associate Professor of Tumor Biology, Department of Tumor Biology, The University of Texas M. D. Anderson Cancer Center, 1515 Holcombe Boulevard, Box 79, Houston, TX 77030

URBA, SUSAN G., M.D., Assistant Professor of Medicine, Division of Hematology/Oncology, Department of Internal Medicine, University of Michigan Medical School, 3119 Taubman Center, Ann Arbor, MI 481090374

VOKES, EVERETT E., M.D., Associate Professor of Medicine, Department of Medicine, Section of Hematology/Oncology, University of Chicago Medical Center, 5841 South Maryland Avenue, MC2115, Chicago, IL 60637-1470

WEBER, RANDAL S., M.D., Associate Professor and Deputy Chairman, Department of Head and Neck Surgery, The University of Texas M. D. Anderson Cancer Center, 1515 Holcombe Boulevard, Box 69, Houston, TX 77030

WEICHSELBAUM, RALPH R., M.D., Harold H. Hines Jr. Professor and Chairman, Department of Radiation and Cellular Oncology, Director, Chicago Tumor Institue, Department of Radiation and Cellular Oncology, University of Chicago Medical Center, 5841 South Maryland Avenue, MC0085, Chicago, IL 60637

WOLF, GREGORY T., M.D., Professor and Chairman, Department of Otolaryngology, University of Michigan Medical School, 1500 East Medical Center Drive, Ann Arbor, MI 48109-0312

ZITSCH, ROBERT P., M.D., Assistant Professor of Surgery, University of Missouri Medical Center, Division of Otolaryngology, One Hospital Drive, Columbia, MO 65201 